\title{
Isolation and prospection of diazotrophic rhizobacteria associated with sugarcane under organic management
}

\author{
ARIANA A. RODRIGUES', MARCUS VINÍCIUS F. ARAÚJO'1, RENAN S. SOARES', BRUNO F.R. \\ DE OLIVEIRA ${ }^{2}$, IGOR D.A. RIBEIRO ${ }^{3}$, SERGIO T. SIBOV ${ }^{4}$ and JOSÉ DANIEL G. VIEIRA ${ }^{1}$ \\ ${ }^{1}$ Laboratório de Microbiologia Ambiental e Biotecnologia, Departamento de Biotecnologia, Instituto de Patologia \\ Tropical e Saúde Pública, Universidade Federal de Goiás, Av. Universitária, s/n, 74605-050 Goiânia, GO, Brazil \\ ${ }^{2}$ Laboratório de Bacteriologia Molecular e Marinha, Departamento de Microbiologia Médica, Instituto de Microbiologia Paulo de \\ Goés, Universidade Federal do Rio de Janeiro, Rua Professor Rodolpho Paulo Rocco, 373, 21941-590 Rio de Janeiro, RJ, Brazil \\ ${ }^{3}$ Centro de Microbiologia Agrícola, Departamento de Genética, Universidade Federal do Rio \\ Grande do Sul, Av. Bento Gonçalves, 9500, 91540-000 Porto Alegre, RS, Brazil \\ ${ }^{4}$ Laboratório de Cultura de Tecidos, Departamento de Genética e Melhoramento de Plantas, Escola de \\ Agronomia, Universidade Federal de Goiás, Av. Esperança, s/n, 74690-900 Goiânia, GO, Brazil.
}

Manuscript received on March 27, 2018; accepted for publication on June 27, 2018

\begin{abstract}
Microorganisms associated with organic management are essential in nutrient transformation and release for plant use. The present study aimed to isolate, identify and characterize plant growth promoting diazotrophic rhizobacteria associated with sugarcane under organic management. Rhizospheres of organic sugarcane varieties IAC 911099 and CTC4 were sampled and inoculated onto nitrogen free NFb and Burk media. The isolated microorganisms were screened in vitro concerning their ability to produce plant growth promoting factors. Eighty-one bacteria were isolated; $45.6 \%$ were positive for the nif $\mathrm{H}$ gene and produced at least one of the evaluated plant growth promotion factors. The production of indole-3-acetic acid was observed in $46 \%$ of the isolates, while phosphate solubilization was observed in $86.5 \%$. No isolates were hydrogen cyanide producers, while $81 \%$ were ammonia producers, $19 \%$ produced cellulases and $2.7 \%$, chitinases. Microorganisms belonging to the Burkholderia genus were able to inhibit Fusarium moniliforme growth in vitro. Plant growth promoting microorganisms associated with organic sugarcane, especially belonging to Burkholderia, Sphingobium, Rhizobium and Enterobacter genera, can be environmentally friendly alternatives to improve sugarcane production.
\end{abstract}

Key words: organic agriculture, plant growth promoting rhizobacteria, nifH, Burkholderia, Sphingobium, Rhizobium.

\section{INTRODUCTION}

The use of petroleum-derived fertilizers and chemical pesticides is a common practice in agriculture. In view of the current scenario, the use

Correspondence to: Ariana Alves Rodrigues

E-mail: ariana.biomed@gmail.com of these inputs is indispensable, making cultivation expensive and, associated with the expansion of the agricultural areas, causing a series of environmental impacts (Goldemberg et al. 2008, Severiano et al. 2009, Schultz et al. 2014). In this sense, a growing interest in cheaper and less environmentally 
impacting alternatives that reduce or replace the use of these implements in traditional agriculture has been observed (Crowder and Reganold 2015, Kanchiswamy et al. 2015).

The use of plant growth promoting rhizobacteria (PGPR) is one of the available alternatives to reduce the use of synthetic fertilizers and products from non-renewable sources, presenting low production/implantation costs (Sadeghi et al. 2012, Szilagyi-Zecchin et al. 2014). PGPR correspond to bacteria that inhabit the rhizosphere, the soil zone immediately adjacent to the root, capable of promoting plant growth by one or more mechanisms (Noumavo et al. 2016). Their use is commonly adopted in traditional agriculture and empirically in organic agriculture, since this type of agriculture is extremely dependent on nutrient transformations mediated by natural soil microbiota (Pariona-Llanos et al. 2010, Bhardwaj et al. 2014, Järvan and Edesi 2015).

PGPR can promote plant growth by increasing plant nutrient availability through nitrogen fixation, mineral solubilization and iron adsorption (Kukla et al. 2014). They can also produce phytostimulators, such as indole-acetic acid (IAA), gibberilinic acid, cytokinins and 1-aminocyclopropane-1carboxylate (ACC) deaminase, which stimulate root development and plant tissue growth (Sgroy et al. 2009). In addition, they play a fundamental role as biopesticides, through the production of metabolites that exhibit antibiotic action, and can also participate in the degradation of organic pollutants (Ahemad and Kibret 2014).

Due to the biological importance of nitrogen in biomolecule constitution and the high costs and environmental impacts caused by the production of synthetic nitrogen fertilizers, nitrogen-fixing bacteria (diazotrophic bacteria) are targets of interest (Karagöz et al. 2012). These microorganisms are able to convert molecular nitrogen $\left(\mathrm{N}_{2}\right)$ into ammonia $\left(\mathrm{NH}_{3}\right)$, a nitrogenous form absorbed by plants. This conversion is mostly mediated by the iron-molybdenum (FeMo) nitrogenase enzyme, which is encoded by the nif complex genes (nif $\mathrm{H}$, nifD, nifK). Because they are highly conserved throughout species, genes from the nif complex can be used as indirect evidence of the presence of nitrogenase and as molecular markers for diazotrophic organism screening (Dai et al. 2014, Ji et al. 2014, Kumar 2014, MacKellar et al. 2016).

Diabotrophic PGPR associated with sugarcane present high taxonomic diversity, with several noteworthy genera, such as Herbaspirillum, Pantoea, Burkholderia, Azospirillum and Glucononacetobacter (Lin et al. 2012, Gopalakrishnan et al. 2015, Tam and Diep 2015). In this scenario, several studies have been conducted to isolate diazotrophic bacteria associated with sugarcane under traditional management and to characterize plant growth promoting factors produced by these organisms (Luvizotto et al. 2010, Lima et al. 2011, Beneduzi et al. 2013, Kruasuwan and Thamchaipenet 2016).

However, research on diazotrophic PGPR associated with sugarcane under organic management is scarce. This group is of great interest, since one of the major challenges of organic agriculture is soil nitrogen limitation, as synthetic nitrogen compounds are abolished (Wongphatcharachai et al. 2015). Thus, PGPR presenting multiple plant growth promotion factors can become a viable alternative in biofertilization, phytostimulation and biocontrol practices in organic sugarcane plantations.

In this context, the present study aimed to isolate and identify diazotrophic rhizobacteria associated with sugarcane under organic management from two sugarcane processing plants located in the state of Goiás, Brazil, and to evaluate plant growth promotion factor production.

\section{MATERIALS AND METHODS}

\section{MICROORGANISM OR BACTERIA ISOLATION}

The microorganism/microbial isolations were conducted from rhizospheric soil obtained from 
two sugarcane varieties (IAC 911099 and CTC4), grown under organic management at farms belonging to two sugarcane processing plants in the cities of Goiatuba ( $19^{\circ} 00^{\prime} 023^{\prime \prime} \mathrm{S}$; $049^{\circ} 40^{\prime}$ $319^{\prime \prime} \mathrm{W}$ ) and Goianésia (15०20' 241" S; $048^{\circ}$ 54' 253” W), Goiás, Brazil. Samplings were carried out from October/2015 to January/2016, and each variety was obtained from four distinct farms, with three replications. Farms with sugarcane specimens planted in different years $(2009,2012,2013$ and 2014) and in different phenological stages were chosen, in order to obtain the greatest possible sample heterogeneity.

Sugarcane roots with adhered rhizospheric soil were conditioned in sterile plastic bags and stored at $4{ }^{\circ} \mathrm{C}$ until processing the following day. The rhizospheric soil was considered as the soil intimately connected to the roots at a distance of up to $5 \mathrm{~mm}$, carefully removed with the aid of a sterilized spatula (Santos et al. 2012).

For isolation of potentially diazotrophic bacteria, $1.0 \mathrm{~g}$ of rhizospheric soil was incubated in $100 \mathrm{~mL}$ of phosphate buffer $(0.8 \% \mathrm{NaCl}, 0.02 \%$ $\mathrm{KCl}, 0.14 \% \mathrm{Na}_{2} \mathrm{HPO}_{4}, 0.024 \% \mathrm{KH}_{2} \mathrm{PO}_{4}, \mathrm{pH} 7.4$ ), under stirring at $130 \mathrm{rpm}$ at $30^{\circ} \mathrm{C}$, for one hour. The obtained suspension was serially diluted and concentrations of $10^{-3}, 10^{-4}$ and $10^{-5}$ were inoculated, in triplicate, in nitrogen-free semi-solid NFb (Dobereiner et al. 1976) and Burk's (Park et al. 2005) media.

The media were then incubated at $30{ }^{\circ} \mathrm{C}$ for 14 days. After growth, in the form of a diffuse film below the surface of the semi-solid medium, the microorganisms were peeled to new semi-solid media. After the growth in semi-solid media (three rounds), the microorganisms were transferred to the corresponding solid media. Microorganism isolation and purification occurred by depletion in solid media. Microorganisms whose colonies displayed the same morphology isolated from the same farm were discarded. After isolation, all colonies were transferred to nutrient agar plates to verify possible bacterial morphotypes isolated simultaneously in the two media. After obtaining pure colonies, the samples were stored in $20 \%$ glycerol $(\mathrm{m} / \mathrm{v})$ at $-20{ }^{\circ} \mathrm{C}$.

\section{DNA EXTRACTION}

DNA extraction was performed from microorganism growth in Luria-Bertani broth (LB) for 24 hours at $30{ }^{\circ} \mathrm{C}$. MoBio's UltraClean ${ }^{\circledR}$ Microbial DNA Isolation Kit was used for DNA extraction, according to the manufacturer's recommendations.

\section{nifH GENE AMPLIFICATION}

The gene encoding the nitrogenase reductase subunit of the enzyme nitrogenase complex (nifH) was amplified to confirm diazotrophic potential. The PCR reaction of the nifH gene was conducted using the oligonucleotide primers PolF (TGCGAYCCSAARGCBGACTC) and PolR (ATSGCCATCATYTCRCCGGA), which generate a product with approximately 360 base pairs (Poly et al. 2001).

The reaction was prepared to a final volume of $10 \mu \mathrm{l}$, consisting of $1 \mathrm{x}$ Taq polymerase buffer, 2.3 $\mathrm{mM} \mathrm{MgCl} 2,0.25 \mathrm{mM}$ of each dNTP, $1.0 \mu \mathrm{M}$ of each primer, $0.2 \mathrm{U}$ of Taq DNA polymerase and $1.0 \mu \mathrm{l}$ of template DNA (50 ng). Amplification was conducted in a thermal cycler by the following cycling steps: initial denaturation at $94{ }^{\circ} \mathrm{C}$ for 5 minutes; followed by 35 denaturation cycles at $94{ }^{\circ} \mathrm{C}$ for 45 seconds, annealing at $57^{\circ} \mathrm{C}$ for 30 seconds, extension at 72 ${ }^{\circ} \mathrm{C}$ for 30 seconds and a final extension step at 72 ${ }^{\circ} \mathrm{C}$ for 1 minute. The reaction products had their integrity confirmed on $1.2 \%(\mathrm{~m} / \mathrm{v})$ agarose gels. The nitrogen fixing strain Azospirillum brasilense was used as a positive control.

\section{DIAZOTROPHIC RHIZOBACTERIA IDENTIFICATION}

All bacteria whose nifH gene can be amplified were identified from the partial sequencing of the $16 \mathrm{~S}$ 
rRNA gene. The reaction was prepared to a final volume of $50 \mu \mathrm{l}$, containing $1 \times$ Taq polymerase buffer, $1.5 \mathrm{mM} \mathrm{MgCl}, 0.2 \mathrm{mM}$ of each dNTP, 0.2 $\mathrm{mM}$ of each primer, $2.5 \mathrm{U}$ of Taq DNA polymerase and $1 \mu \mathrm{l}$ of template DNA (50 ng). The $16 \mathrm{~S}$ region was amplified using primers 27F (5'-AGA GTT TGA TCC TGG CTC AG-3') and 1541R (5'AAG GAG GTG ATC CAG CC-3') (Lane 1991). DNA was amplified in a thermal cycler, under the following conditions: initial denaturation at $95{ }^{\circ} \mathrm{C}$ for 3 minutes; followed by 30 denaturation cycles at $94{ }^{\circ} \mathrm{C}$ for 1 minute, annealing at $55^{\circ} \mathrm{C}$ for 30 seconds, extension at $72{ }^{\circ} \mathrm{C}$ for 30 seconds and a final extension step at $72{ }^{\circ} \mathrm{C}$ for 10 minutes.

The amplified products had their integrity confirmed on $1.2 \%$ agarose gels and purified with isopropanol and ethanol using the method described by Sambrook and Russell (2001). Sequencing was conducted on the ABI 3130xl platform (Applied Biosystems), using the BigDye terminator cycle sequencing kit and the oligonucleotide primers 27 F, 530F (5'-TGA CTG ACT GAG TGC CAG CMG CCG CGG-3') and 519R (5'-GTN TTA CNG CGG CKG CTG -3') (Lane 1991).

The reads obtained from the sequencing of each microorganism were evaluated regarding quality. Subsequently, the sequences (reads) were joined in a single sequence (contig). These steps were performed using the CodonCode Aligner software, version 6.0.2. Then, the sequences were compared to those deposited at the NCBI (National Center for Biotechnology Information) 16S rRNA library using the BLAST tool (Altschul et al. 1990). The identified sequences were deposited at the NCBI 16S rRNA database under accession numbers MG429815 to MG429819; MG459255 to MG459472 and MG459472.

In vitro SCREENING FOR PLANT GROWTH PROMOTING TRAITS

Microorganisms positive for the nifH gene were screened, in vitro, regarding their IAA, phosphate solubilization, ammonia, hydrogen cyanide $(\mathrm{HCN})$, celulase and chitinase production capacity and antagonism to Fusarium moniliforme. All evaluations were carried out in triplicate and the results are expressed as the means of the replicates.

\section{IAA PRODUCTION}

Rhizobacteria ability to produce IAA was quantitatively determined by the method described by Gordon and Weber (1951), with modifications. The microorganisms were adjusted to a concentration of $10^{8}$ cells $\mathrm{mL}^{-1}\left(\mathrm{OD}_{550 \mathrm{~nm}}=0.1\right)$ and inoculated in 10\% tripticasein soy broth (TSB), supplemented with $5 \mathrm{mM}$ L-tryptophan. Growth aliquots were removed after 24, 48 and 72 hours and centrifuged for 12 minutes at $10,000 \mathrm{xg}$. The Salkowisk reagent (35\% perchloric acid and $1 \mathrm{ml}$ of $0.5 \mathrm{M} \mathrm{FeCl}_{3}$ ) was added to the culture supernatants at a $1: 1(\mathrm{v}: \mathrm{v})$ ratio and the solutions were then incubated at room temperature, in the dark, for 30 minutes. After incubation, absorbances were determined on a spectrophotometer at $530 \mathrm{~nm}$. IAA concentrations were determined by comparison to a standard curve constructed from a commercial IAA solution $\left(0 \mu \mathrm{g} \mathrm{mL}^{-1} ; 1.0 \mu \mathrm{g} \mathrm{mL}^{-1} ; 5.0 \mu \mathrm{g} \mathrm{mL}^{-1}\right.$; $10 \mu \mathrm{g} \mathrm{mL}^{-1} ; 25 \mu \mathrm{g} \mathrm{mL}^{-1} ; 50 \mu \mathrm{g} \mathrm{mL}^{-1} ; 75 \mu \mathrm{g} \mathrm{mL}^{-1}$; $100 \mu \mathrm{g} \mathrm{mL}^{-1} ; 150 \mu \mathrm{g} \mathrm{mL}^{-1} ; 200 \mu \mathrm{g} \mathrm{mL}^{-1}$ ). Resuls

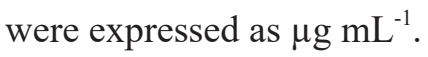

\section{PHOSPHATE SOLUBILIZATION}

Phosphate solubilization was quantitatively determined according to Nautiyal (1999). The microorganisms were adjusted to a concentration of $10^{8}$ cells $\mathrm{mL}^{-1}\left(\mathrm{OD}_{550 \mathrm{~nm}}=0.1\right)$ and inoculated, in triplicate, in NBRIP broth (Nautiyal 1999). The samples were incubated for 7 days at $30^{\circ} \mathrm{C}$, under agitation at $130 \mathrm{rpm}$. After incubation, 1,000 $\mu \mathrm{l}$ aliquots were centrifuged at $10,000 \mathrm{xg}$ for 5 minutes. Soluble phosphorus content was determined by the addition of the molybdate-vandate reagent (5.0\% ammonium molybdate, $0.25 \%$ ammonium 
vanadate) to the supernatants at the following ratio: $200 \mu 1$ supernatant, $200 \mu 1$ reagent and 600 $\mu 1$ distilled water. Solution absorbances were determined on a spectrophotometer at $420 \mathrm{~nm}$. Soluble phosphate concentrations expressed as $\mu \mathrm{g} \mathrm{mL}^{-1}$ were obtained by comparison to a standard curve constructed from a stock $\mathrm{KH}_{2} \mathrm{PO}_{4}$ $(0.0875 \%)$ solution and different soluble phosphate concentrations $\left(0 \mu \mathrm{g} \mathrm{mL}^{-1} ; 1.0 \mu \mathrm{g} \mathrm{mL}^{-1} ; 5.0 \mu \mathrm{g} \mathrm{mL}^{-}\right.$ ${ }^{1} ; 8.0 \mu \mathrm{g} \mathrm{mL}^{-1} ; 10 \mu \mathrm{g} \mathrm{mL}^{-1} ; 12 \mu \mathrm{g} \mathrm{mL}^{-1} ; 15 \mu \mathrm{g} \mathrm{mL}^{-1}$; $\left.18 \mu \mathrm{g} \mathrm{mL}^{-1} ; 20 \mu \mathrm{g} \mathrm{mL}^{-1} ; 50 \mu \mathrm{g} \mathrm{mL}^{-1} ; 75 \mu \mathrm{g} \mathrm{mL}^{-1}\right)$.

\section{AMMONIA AND HCN PRODUCTION}

For ammonia production evaluation, microorganisms were inoculated in peptone water and incubated at $30{ }^{\circ} \mathrm{C}$ for 7 days. After centrifugation at $10,000 \mathrm{xg}$ for 10 minutes, the Nessler reagent $\left(10 \% \mathrm{HgI}_{2}, 7.0 \% \mathrm{KI}\right.$ and $50 \%$ aqueous $\mathrm{NaOH} 32 \%$ solution) was added to the supernatants at a 2:1 (v/v) ratio (Cappuccino and Sherman 1996). The development of a brown color was considered indicative of ammonia production (Dey et al. 2004).

$\mathrm{HCN}$ production was determined according to the technique described by Cattelan (1999), with modifications. Isolates were initially grown for 24 hours in $10 \%$ tripticasein soybean (TSA) agar, supplemented with $0.4 \%$ glycine. After microorganism growth, filter papers (Whatman \# 1) embedded in a picric acid solution $(0.5 \%$ picric acid and $2.0 \% \mathrm{Na}_{2} \mathrm{CO}_{3}$ ) were deposited on the plate lids. The plates were then again incubated for 48 hours. Positive HCN production was considered when the filters became brownish (Walpola and Yoon 2013).

\section{CHITINASE AND CELULASE PRODUCTION}

The ability of the isolates to produce chitinases was verified according to Cattelan (1999). Briefly, microorganisms were cultured for 14 days at 30 ${ }^{\circ} \mathrm{C}$ in nitrogen-free medium (MNL) supplemented with $8.0 \mathrm{~g} \mathrm{~L}^{-1}$ of colloidal chitin, $0.78 \mathrm{~g} \mathrm{~L}^{-1} \mathrm{NH}_{4} \mathrm{NO}_{3}$ and $15 \mathrm{~g} \mathrm{~L}^{-1}$ agar. The addition of chitin generates turbidity in the medium. A clear halo around the colony is observed when microorganism display the ability to degrade the chitin.

Cellulase production evaluation was carried out by culturing the microorganisms in minimal medium containing carboxymethylcellulose (CMC) (Stamford et al. 1998). After growth at 30 ${ }^{\circ} \mathrm{C}$ for 48 hours, the plates were covered with a $0.3 \%$ Lugol solution. The presence of light halos around the colony were indicative of cellulase production (Kasana et al. 2008). For all evaluated enzymes, the enzymatic index (EI) was determined, obtained by dividing the size of the halo by the size of the colony.

\section{ANTAGONISM AGAINST F. moniliforme}

Bacteria were evaluated, in vitro, regarding their ability to inhibit the phytopathogenic fungus F. moniliforme, according to the methodology described by El-Sayed et al. (2014), with modifications. The microorganisms were initially cultured in TSA broth at $30^{\circ} \mathrm{C}$ for 48 hours. Subsequentyl, they were inoculated into two parallel striae, $1.5 \mathrm{~cm}$ distant from the plate border, in potato dextrose agar. A $5 \mathrm{~mm}$ diameter disc with fungus growth was placed in the center of the plate, previously cultured for 7 days at $30{ }^{\circ} \mathrm{C}$ in potato dextrose agar. After 7 days, the ability of the isolates to inhibit fungal growth was evaluated by measuring the distance between the bacterial colony and the fungal colony. A plaque without the bacterial inoculum was used as a negative control.

\section{STATISTICAL ANALYSES}

The data obtained from the in vitro tests were submitted to an analysis of variance (ANOVA) and means were compared applying the Scott-Knott test at a $5.0 \%$ significance using the Sisvar software, version 5.6 (Ferreira 2011). When necessary, data 
that did not present homogeneous variances or normal distribution were log corrected.

\section{RESULTS}

\section{MICROORGANISM ISOLATION AND IDENTIFICATION}

Eighty-one sugarcane rhizosphere bacteria were isolated from sugarcane under organic management in nitrogen-free culture media. For the purposes of isolate nomenclature, the first letter corresponds to the isolation medium ( $\mathrm{B}=$ Burk and $\mathrm{N}=\mathrm{NFB})$, the second, to the sugarcane variety $(\mathrm{C}=\mathrm{CTC} 4$ and $\mathrm{U}$ $=$ IAC 911099), and the numbers refers to farm and striking order, respectively (Table I). Regarding origin, $57.3 \%$ of the bacteria were isolated from the CTC4 variety and $42.7 \%$ from the IAC 911099 variety. The nif $\mathrm{H}$ gene was amplified in $45.6 \%$ of the isolates. All bacteria whose nif $\mathrm{H}$ gene could be amplified produced more than one mechanism to promote plant growth, characterizing them as rhizobacteria carrying multiple plant growth promoting factors.

The 37 diazotrophic microorganisms identified by the partial sequencing of the $16 \mathrm{~S}$ rRNA gene were distributed throughout 13 genera (Table I). The size of the obtained fragments varied from 473 to 1467 base pairs, with similarity between 97 and 99\% (Table I).

The most common genera detected were Burkholderia, Bacillus and Rhizobium, with 15, 6 and 3 isolates, respectively. In addition, bacteria belonging to the Cupriavidus $(\mathrm{n}=2)$, Dyella $(\mathrm{n}=1)$, Enterobacter $(\mathrm{n}=2), \operatorname{Erwinia}(\mathrm{n}=1)$, Flavobacterium $(\mathrm{n}=1)$, Methylobacterium $(\mathrm{n}=1)$, Mitsuaria $(\mathrm{n}=1)$, Sphingobium $(\mathrm{n}=2)$, Sphingomonas $(\mathrm{n}=1)$ and Variovorax $(\mathrm{n}=1)$ genera were also detected. The classification of isolates NC92, BC26, NU45, NU92, NU32, BU97, BU32, BU92, NC93, BC91 and BU24 occurred at the species level, supported by $99 \%$ similarity values (Table I).
All microorganisms belonging to the Bacillus genus were isolated from the CTC4 variety and found in most of the investigated sugarcane processing farms. The Burkholderia genus, however, was most frequently associated with IAC 911099 variety (Table I). The microorganism Sphingobium yanoikuyae (BU32 and BU92) was isolated from different locations and in the same sugarcane variety, while Rhizobium tropici (BC91 and BU24) was isolated from different localities and varieties (Table I).

\section{In vitro SCREENING FOR PLANT GROWTH PROMOTING TRAITS}

IAA production was observed in $46 \%$ of the evaluated diazotrophic isolates. The produced IAA concentrations ranged from 0.5 to $36.15 \mu \mathrm{g} \mathrm{mL}{ }^{-1}$ in 24 hours, from 0.5 to $59.48 \mu \mathrm{g} \mathrm{mL}^{-1}$ in 48 hours and 0.23 to $87.07 \mu \mathrm{g} \mathrm{mL}^{-1}$ in 72 hours (Table II). At 72 hours, most isolates produced over $20 \mu \mathrm{g}$ $\mathrm{mL}^{-1}$ IAA. The highest IAA value was produced by Sphingobium yanoikuyae (BU32), followed by microorganisms belonging to the Sphingobium (BU92), Sphingomonas (BC44), Enterobacter (NC25 and NU33) and Rhizobium (NC24) genera.

The ability to solubilize phosphate was observed in $86.5 \%$ of the evaluated isolates, ranging from 1.82 to $53.78 \mu \mathrm{g} \mathrm{mL}^{-1}$ (Table II). Microorganisms belonging to the Burkholderia genus were noteworthy regarding phosphate solubilization, solubilizing $53.78 \mu \mathrm{g} \mathrm{mL}^{-1}$ (NC97), $50.08 \mu \mathrm{g} \mathrm{mL}^{-1}$ (NU93), $50.03 \mu \mathrm{g} \mathrm{mL}^{-1}$ (BU95), $45.82 \mu \mathrm{g} \mathrm{mL}^{-1}$ (NU92) and $44.8 \mu \mathrm{g} \mathrm{mL}^{-1}$ (BC43). It is importante to note that Sphingobium yanoikuyae (BU32), Rhizobium sp. (NC24), Enterobacter sp. (NC25) and Enterobacter sp. (NU33) as well as being the best IAA producers, were also efficient regarding phosphate solubilization (Table II).

Ammonia production was detected in $81 \%$ of the isolates, being the second most common plant growth promotion factor, after phosphate solubilization. In addition to nitrogen fixation 
TABLE I

Rhizobacteria isolated from sugarcane under organic management identification based on comparisons with 16S rRNA region sequences deposited at the GenBank database.

\begin{tabular}{|c|c|c|c|c|c|}
\hline $\begin{array}{c}\text { Isolate } \\
\text { identification* }\end{array}$ & Fragment size & Nearest species & Similarity & $\begin{array}{c}\text { Accession number } \\
\text { of the nearest } \\
\text { species }\end{array}$ & Deposit number \\
\hline BC211 & 1171 & Burkholderia sp. & $97 \%$ & NR_026462.1 & MG459286 \\
\hline $\mathrm{BC} 23$ & 961 & Bacillus aryabhattai & $99 \%$ & NR_115953.1 & MG459285 \\
\hline $\mathrm{BC} 26$ & 473 & Bacillus megaterium & $99 \%$ & NR_117473.1 & MG459284 \\
\hline $\mathrm{BC} 27$ & 1443 & Bacillus sp. & $97 \%$ & NR_116873.1 & MG459283 \\
\hline $\mathrm{BC} 28$ & 1071 & Bacillus sp. & $98 \%$ & NR_148626.1 & MG459282 \\
\hline $\mathrm{BC} 42$ & 1255 & Cupriavidus sp. & $98 \%$ & NR_113619.1 & MG459281 \\
\hline $\mathrm{BC} 43$ & 1246 & Burkholderia sp. & $98 \%$ & NR_041720.1 & MG459280 \\
\hline $\mathrm{BC} 44$ & 522 & Sphingomonas sp. & $99 \%$ & NR_113637.1 & MG459279 \\
\hline ВC91 & 1183 & Rhizobium tropici & $99 \%$ & NR_102511.1 & MG459278 \\
\hline ВC93 & 723 & Burkholderia sp. & $97 \%$ & NR_102890.1 & MG459277 \\
\hline BC95 & 1241 & Burkholderia sp. & $99 \%$ & NR_042632.1 & MG459276 \\
\hline BU23 & 1239 & Burkholderia sp. & $98 \%$ & NR_126274.1 & MG459275 \\
\hline BU24 & 1170 & Rhizobium tropici & $99 \%$ & NR_102511.1 & MG459274 \\
\hline BU32 & 777 & Sphingobium yanoikuyae & $99 \%$ & NR_113730.1 & MG429815 \\
\hline BU92 & 1197 & Sphingobium yanoikuyae & $99 \%$ & NR_113730.1 & MG459272 \\
\hline BU95 & 1229 & Burkholderia sp. & $99 \%$ & NR_136496.1 & MG459271 \\
\hline BU96 & 1266 & Dyella sp. & $97 \%$ & NR_043258.1 & MG459270 \\
\hline BU97 & 1258 & Burkholderia vietnamiensis & $99 \%$ & KF114029.1 & MG459269 \\
\hline BU98 & 1138 & Burkholderia sp. & $97 \%$ & NR_114491.1 & MG459268 \\
\hline $\mathrm{NC} 24$ & 724 & Rhizobium sp. & $97 \%$ & FN645738.1 & MG459267 \\
\hline $\mathrm{NC} 25$ & 1233 & Enterobacter $\mathrm{sp}$. & $97 \%$ & NR_146667.2 & MG459266 \\
\hline $\mathrm{NC} 26$ & 1467 & Flavobacterium sp. & $97 \%$ & NR_134727.1 & MG459265 \\
\hline $\mathrm{NC} 27$ & 1168 & Bacillus sp. & $97 \%$ & NR_118442.1 & MG459472 \\
\hline NC29 & 1118 & Cupriavidus sp. & $97 \%$ & NR_113619.1 & MG459264 \\
\hline $\mathrm{NC} 43$ & 535 & Erwinia sp. & $97 \%$ & NR_074869.1 & MG459263 \\
\hline NC49 & 1253 & Methylobacterium sp. & $99 \%$ & NR_074244.1 & MG459262 \\
\hline NC92 & 631 & Bacillus megaterium & $99 \%$ & NR_117473.1 & MG429816 \\
\hline NC93 & 1090 & Variovorax soli & $99 \%$ & NR_043811.1 & MG459261 \\
\hline NC97 & 755 & Burkholderia sp. & $99 \%$ & NR_104975.1 & MG429817 \\
\hline NU21 & 1406 & Burkholderia sp. & $99 \%$ & NR_113645.1 & MG459260 \\
\hline NU31 & 1082 & Burkholderia sp. & $99 \%$ & NR_114491.1 & MG459259 \\
\hline NU32 & 770 & Burkholderia gladioli & $99 \%$ & NR_113629.1 & MG429818 \\
\hline NU33 & 1376 & Enterobacter sp. & $99 \%$ & KF010362.1 & MG459258 \\
\hline NU41 & 769 & Mitsuaria sp. & $98 \%$ & NR_114070.1 & MG429819 \\
\hline NU45 & 1279 & Burkholderia ambifaria & $99 \%$ & NR_074687.1 & MG459257 \\
\hline NU92 & 1197 & Burkholderia cepacia & $99 \%$ & NR_114491.1 & MG459256 \\
\hline NU93 & 1339 & Burkholderia sp. & $99 \%$ & NR_114491.1 & MG459255 \\
\hline
\end{tabular}

* Regarding isolate nomenclature: N/B corresponds to the isolation medium (NFB and Burk) and C/U correspond to the variety (C $=\mathrm{CTC} 4$ and $\mathrm{U}=\mathrm{IAC} 1099)$. 
capacity, ammonia production was the only plant growth promoter observed for isolates Methylobacterium sp. (NC49), Mitsuaria sp. (NU41) and Variovorax soli (NC93). HCN production was not observed in any of the isolates.

Cellulase producers accounted for $19 \%$ of the isolates, with enzymatic indices ranging from 1.5 and 3.41. Most of the cellulase-producing isolates belonged to the Bacillus genus (BC23, BC26, $\mathrm{BC} 27, \mathrm{BC} 28$ and $\mathrm{NC} 27)$, but representatives of the Flavobacterium (NC26) and Sphingobium (BU32) genera were also proven as enzyme producers (Table II). Only Dyella sp. (BU96) was chitinaseproducing, with an enzyme index of 2.8 (Table II).

The ability to inhibit the pathogenic fungus F. moniliforme was observed for $21.7 \%$ of the isolates. All isolates displaying antagonism to the pathogenic fungus belonged to the Burkholderia genus. Isolates NC97, BU95, NU21, NU31 and NU45 exhibited the greatest distances between the fungal and bacterial colonies (Table II). It is noteworthy that not all microorganisms that presented fungus antagonism were indirect plant growth mechanisms producers (ammonia, HCN, cellulases and chitinases), responsible for pathogen attacks.

\section{DISCUSSION}

In the present study, 81 microorganisms from sugarcane under organic management were isolated using $\mathrm{NFb}$ and Burk nitrogen-free semi-solid media. The bacteria were isolated based on their morphological diversity, which takes into account characteristics such as color, contour and elevation wich allows to classify the bacteria differentially (Di Franco et al. 2002). This strategy was used to capture the largest number of isolates belonging to different species and to maximize resources. On the other hand, when discarding morphologically equivalent microorganisms, some species may have been underestimated, since there is no genetic evidence that two similar colonies are of the same species (Lebaron et al. 1998).

Although the NFb medium facilitates the isolation of bacteria belonging to the Azospirillum genus (Kuss et al. 2007), several studies using this medium have described the isolation of other genera, such as Gluconacetobacter, Herbaspirillum, Burkholderia, Bacillus, Enterobacter, Klebsiella, Pantoea and Pseudomonas (Ambrosini et al. 2012, Tam and Diep 2015). On the other hand, Burk's medium is not specific, being associated to a range of fixing species (Park et al. 2005). Semisolid nitrogen free media are considered ideal for diazotrophic bacteria isolation and screening. The reduced agar concentration determines an ideal microaerophilic condition for nitrogenase action, reduced in high oxygen concentrations (Baldani et al. 2014).

The isolation and application of diazotrophic bacteria in crops under organic regimes is extremely interesting from an agricultural point of view, since the great limitation of organic crops is precisely the available nitrogen supply. Diazotrophic microorganisms could be applied as substitutes to synthetic fertilizers (Wongphatcharachai et al. 2015) or in association with animal and vegetable manure, usually used as nitrogen sources in organic crops (Hirel et al. 2011).

The nif $\mathrm{H}$ gene, being conserved throughout species, is often used as molecular marker for the screening of nitrogen-fixing bacteria (Raymond et al. 2004, Gaby and Buckley 2012) and was amplified in $45.6 \%$ of the isolates detected in this study. The fact that the nif $\mathrm{H}$ gene has not been amplified, however, does not mean that the microorganism is not fixative. The sequence of the main widely used primers, mostly constituted by degenerate bases, are designed to flank the same region or overlapping sites, restricting their reach (Poly et al. 2001, Zehr et al. 2003). In addition, not all organisms exhibit iron-molybdenum nitrogenase (nif), since other nitrogenases also exist, differentiated by the metal 
TABLE II

In vitro production of plant growth promoting traits by diazotrophic bacteria isolated from sugarcane under organic management ${ }^{1}$.

\begin{tabular}{|c|c|c|c|c|c|c|c|c|}
\hline \multirow[t]{2}{*}{ Isolate } & \multicolumn{3}{|c|}{ IAA $\left(\mu \mathrm{g} \mathrm{mL^{-1 }}\right)$} & \multirow{2}{*}{ Phosphate $\left(\mu \mathrm{g} \mathrm{mL} \mathrm{L}^{-1}\right)$} & \multirow{2}{*}{ Amo } & \multirow{2}{*}{$\mathrm{Cel}^{2}$} & \multirow{2}{*}{ Chit $^{2}$} & \multirow{2}{*}{$\mathbf{A n t}^{3}$} \\
\hline & $24 \mathrm{~h}$ & $48 \mathrm{~h}$ & $72 \mathrm{~h}$ & & & & & \\
\hline BC211 & 0 & 0 & 0 & $26.29 \mathrm{~g}$ & + & - & - & - \\
\hline $\mathrm{BC} 23$ & 0 & 0 & 0 & $18.11 \mathrm{f}$ & + & $2.71 \mathrm{a}$ & - & - \\
\hline $\mathrm{BC} 26$ & 0 & 0 & 0 & $13.36 \mathrm{e}$ & - & $3.41 \mathrm{a}$ & - & - \\
\hline $\mathrm{BC} 27$ & 0 & 0 & 0 & $12.59 \mathrm{e}$ & + & $2.20 \mathrm{a}$ & - & - \\
\hline $\mathrm{BC} 28$ & 0 & 0 & 0 & $3.32 b$ & + & $2.00 \mathrm{a}$ & - & - \\
\hline BC42 & 0 & 0 & 0 & $1.82 \mathrm{a}$ & + & - & - & - \\
\hline $\mathrm{BC} 43$ & 0 & 0 & $1.19 \mathrm{~b}$ & $44.81 \mathrm{i}$ & + & - & - & - \\
\hline $\mathrm{BC} 44$ & 0 & $27.46 f$ & $48.65 \mathrm{~h}$ & 0 & + & - & - & - \\
\hline ВC91 & 0 & 0 & $9.85 \mathrm{e}$ & $10.20 \mathrm{~d}$ & - & - & - & - \\
\hline ВC93 & 0 & 0 & 0 & $26.57 \mathrm{~g}$ & - & - & - & - \\
\hline ВC95 & $4.49 \mathrm{c}$ & $16.25 \mathrm{e}$ & $14.04 \mathrm{f}$ & $29.12 \mathrm{~g}$ & + & - & - & - \\
\hline BU23 & 0 & 0 & 0 & $27.67 \mathrm{~g}$ & + & - & - & - \\
\hline BU24 & $2.47 \mathrm{~b}$ & $3.25 \mathrm{~b}$ & $6.06 \mathrm{~d}$ & $6.66 \mathrm{c}$ & + & - & - & - \\
\hline BU32 & $36.15 \mathrm{e}$ & $43.22 \mathrm{~g}$ & $87.07 \mathrm{~h}$ & $34.29 \mathrm{~h}$ & - & $3.00 \mathrm{a}$ & - & - \\
\hline BU92 & $25.84 \mathrm{e}$ & $59.48 \mathrm{~g}$ & $63.68 \mathrm{~h}$ & 0 & + & - & - & - \\
\hline BU95 & 0 & 0 & 0 & $50.03 \mathrm{i}$ & + & - & - & $6 a$ \\
\hline BU96 & 0 & 0 & 0 & $9.64 d$ & + & - & $2.8 \mathrm{a}$ & - \\
\hline BU97 & 0 & 0 & $4.15 c$ & $10.57 \mathrm{~d}$ & + & - & - & $3 b$ \\
\hline BU98 & 0 & $11.55 \mathrm{~d}$ & $30.23 \mathrm{~g}$ & $26.98 \mathrm{~g}$ & + & - & - & - \\
\hline $\mathrm{NC} 24$ & $23.59 \mathrm{e}$ & $48.73 \mathrm{~g}$ & $64.52 \mathrm{~h}$ & $33.23 \mathrm{~h}$ & + & - & - & - \\
\hline $\mathrm{NC} 25$ & $22.81 \mathrm{e}$ & $50.52 \mathrm{~g}$ & $80.42 \mathrm{~h}$ & $38.56 \mathrm{~h}$ & + & - & - & - \\
\hline $\mathrm{NC} 26$ & 0 & 0 & 0 & $16.14 \mathrm{f}$ & + & $1.50 \mathrm{a}$ & - & - \\
\hline $\mathrm{NC} 27$ & 0 & 0 & 0 & $24.96 \mathrm{~g}$ & - & $2.60 \mathrm{a}$ & - & - \\
\hline NC29 & 0 & 0 & 0 & $15.64 f$ & + & - & - & - \\
\hline $\mathrm{NC} 43$ & 0 & 0 & $23.29 \mathrm{~g}$ & $35.32 \mathrm{~h}$ & + & - & - & - \\
\hline NC49 & 0 & 0 & 0 & 0 & + & - & - & - \\
\hline NC92 & 0 & 0 & 0 & $6.54 \mathrm{c}$ & + & - & - & - \\
\hline NC93 & 0 & 0 & 0 & 0 & + & - & - & - \\
\hline NC97 & $0.5 \mathrm{a}$ & $0.5 \mathrm{a}$ & $3.37 \mathrm{c}$ & $53.78 \mathrm{i}$ & - & - & - & $7 \mathrm{a}$ \\
\hline NU21 & 0 & 0 & 0 & $38.89 \mathrm{~h}$ & + & - & - & $5 \mathrm{a}$ \\
\hline NU31 & 0 & 0 & $0.23 \mathrm{a}$ & $32.98 \mathrm{~h}$ & + & - & - & $5 \mathrm{a}$ \\
\hline NU32 & 0 & 0 & 0 & $15.09 \mathrm{f}$ & - & - & - & - \\
\hline NU33 & $28.49 \mathrm{e}$ & $37.85 \mathrm{f}$ & $77.41 \mathrm{~h}$ & $34.37 \mathrm{~h}$ & + & - & - & - \\
\hline NU41 & 0 & 0 & 0 & 0 & + & - & - & - \\
\hline NU45 & 0 & $2.25 \mathrm{~b}$ & $2.9 \mathrm{c}$ & $15.45 \mathrm{f}$ & + & - & - & $4 a$ \\
\hline NU92 & $8.92 d$ & $9.29 \mathrm{~d}$ & $9.63 \mathrm{e}$ & $45.82 \mathrm{i}$ & + & - & - & $3 b$ \\
\hline NU93 & 0 & 0 & 0 & $50.08 \mathrm{i}$ & + & - & - & $2 \mathrm{c}$ \\
\hline
\end{tabular}

$\mathrm{IAA}=$ production of 3 -indole-acetic acid $;$ Phosphate $=$ phosphate solubilization; Amo $=$ Ammonia $;$ Cel $=$ Cellulase $;$ Chit $=$ Chitinase; Ant $=$ antagonism. ${ }^{1 .}$ Means followed by the same letters do not differ statistically by Scott-Knott's test at a 5\% probability. ${ }^{2 .}$ The expressed values correspond to the enzymatic index, obtained by dividing the diameter of the halo by that of the colony. The "-" label indicates bacterial growth without halo formation and label "+" indicates a positive test. ${ }^{3 .}$ The values presented correspond to the distance between the fungal and bacterial colony. The label "-" indicates that the bacterium was not antagonistic to the fungus. 
contained in their structures, such as iron-vanadium nitrogenase (Vnf) or iron nitrogenase (Anf) (Dahal et al. 2017).

Other microorganisms are capable of growing in nitrogen-free media and are not fixers. It has been suggested that these organisms may incorporate ammonia or other nitrogen species at very low concentrations, or that they are capable of using fractions fixed by other organisms (Beneduzi et al. 2013, MacKellar et al. 2016). In addition, we emphasize that the amplification of the nif $\mathrm{H}$ gene has a confirmatory character, but cannot quantify the amount of fixed nitrogen, and the use of techniques such as acetylene reduction (ARA) and the incorporation of the ${ }^{15} \mathrm{~N}_{2}$ isotope is recommended (Gtari et al. 2012).

The genus most detected in this study, Burkholderia, is widely distributed in nature and is often found associated with sugarcane under traditional management (Luvizotto et al. 2010, Castro-Gonzalez et al. 2011). From the point of view of organic agriculture, the Burkholderiaceae family and nifH genes have been reported as being more abundant in agricultural soils abundant in swine manure (Xun et al. 2018). In addition to their ability to fix nitrogen, it is also suggested that plant growth promotion performed by these organisms is associated with the production of IAA, phosphate solubilization and in vitro pathogen inhibition (Paungfoo-Lonhienne et al. 2014).

The genus Bacillus, the second most detected in the present study, has also been described in association with sugarcane under traditional management and presents potential regarding the production of enzymes of agronomic interest (Beneduzi et al. 2008, Madhaiyan et al. 2011, Pisa et al. 2011). The other genera found herein have been mostly associated with sugarcane under traditional management or cultivated soils (Nicolaisen et al. 2008, Burbano et al. 2011, Anand et al. 2012, Bers et al. 2012, Santi Ferrara et al. 2012, Fischer et al.
2012, Lin et al. 2012, Hoang et al. 2015, Solanki et al. 2017).

The presence of Bacillus and Burkoholderia as more predominant groups was also observed by Xia et al. (2015), when evaluating the taxonomic distribution of maize, melon, pepper and tomato bacteria in organic systems. Oliveira (2009) using selective media for nitrogen fixers, including $\mathrm{NFb}$, observed a range of microorganisms associated with sugarcane plantations under organic management in São Paulo, Brazil, with emphasis on Enterobacter, Klebsiella, Pseudomonas, Burkholderia and Beijerinckia species. Those authors also detected other species, such as Agrobacterium, Azozpirillum, Bosea, Bradyrhizobium, Brucella, Cohnella, Erwinia, Gluconacetobacter, Rhizobium, Stenotrophomonas, Variovorax and Xanthomonas.

The similarities and divergences of this study in relation to the study conducted by Oliveira (2009) reinforce the idea that, even if Enterobacter, Burkholderia and Rhizobium species are ubiquitous, factors such as plant age, variety, root exudates, management and soil chemical and physical attributes can influence the community distribution and species (Beneduzi et al. 2008, 2013, Santi Ferrara et al. 2012, Noumavo et al 2016). Therefore, for each evaluated region, distinct distribution patterns of diazotrophic microorganisms are observed, which is interesting regarding PGPR prospecting.

Less than half of the evaluated isolates produced IAA, and a broad taxonomic variety was observed among the best producers. In addition, some individuals belonging to the same genus produced distinct IAA values and were classified into different groups, according to Scot-Knott's test at a $5.0 \%$ probability. Enterobacter sp. NC25 and NU33 strains produced 80.42 and $77.41 \mathrm{mg}$ $\mathrm{mL}^{-1}$, respectively, similar to the strains reported by Rodrigues et al. (2016) when evaluating Enterobacter sp. rhizospheres from traditionally managed sugarcane. 
Although IAA production is commonly found among rhizobacteria (Sagar et al. 2017), different types of fertilizers impact on the number of bacteria in the soil and the diversity of bacteria producing this compound. In systems where, chemical fertilizers are withdrawn or where organic fertilizers are applied, the number and diversity of IAA-producing bacteria increases. The use of organic fertilizers improves the structure of the microbial community, in addition to selecting beneficial microorganisms (Yuan et al. 2011, Duangpaeng et al. 2012).

In addition to being the most active auxin, it is believed that IAA is physiologically active even at low concentrations, so even organisms that produce small IAA fractions may be able to contribute to plant health (Hayat et al. 2010, Vejan et al. 2016). IAA production leads to increased lateral roots, in addition to increasing root surface area and size, leading to increased water and nutrient supplies to plants (Brandl and Lindow 1998, Vessey 2003).

The ability to solubilize phosphate was the most common feature of the diazotrophic bacteria evaluated herein, with emphasis on bacteria belonging to the Burkholderia genus. In the case of sugarcane rizobacteria under traditional management, Inui-Kushi et al. (2012) verified that Burkholderia bacteria displayed with the highest phosphate solubilization index among 10 different bacteria belonging to the same genus.

Although not a mandatory feature of the Burkholderia genus, several species belonging to this genus have been associated with varying phosphate solubilization and rhizosphere acidity levels (Castro-Gonzalez et al. 2011). When studying the impact of organic management on the diversity of pepper phosphate-solubilizing bacteria (Capsicum frutescens L. cv. Hua Rua), Surapat et al. (2013) observed that most of their phosphate-solubilizing isolates were recovered from organic systems, and thet most belonged to the Burkholderia genus.
The most well-known phosphate solubilization mechanism involves medium acidification. Plants display the ability to acidify the rhizosphere, leading to phosphate solubilization, although this capacity is quite limited (Hamdali et al. 2008). It is suggested that even the phosphate solubilized in small amounts by bacteria still corresponds to a large part of the soluble phosphate available to plants, especially in organic crops, that are largely dependent on the natural soil microbiota and that display high amounts of organic phosphates (Pariona-Llanos et al. 2010).

Ammonia production is quite common among rhizobacteria, as observed in this study and in studies conducted by Joseph et al. (2007) and Gayathri et al. (2010). HCN production is rare, a fact corroborated by Kavamura et al. (2013) when evaluating bacteria obtained from cacti. Ammonia and HCN are volatile compounds that act as biocontrol agents. In addition to acting as pathogen responses, it is believed that ammonia can be used as a source of nitrogen supplementation by the host plant (Joseph et al. 2007, Marques et al. 2010, Passari et al. 2015). A study conducted by Marques et al. (2010) observed that ammonia production was positively correlated to nitrogen and phosphorus accumulation, root and stem elongation and biomass increases in maize.

The present study observed that most cellulaseproducing isolates belonged to the Bacillus genus, similarly to the results reported by Zhao et al. (2015). Cellulase-producing microorganisms belonging to the Bacillus genus are widely distributed in the sugarcane rhizosphere. They are believed to participate in the degradation of cellulolytic debris originating from the plant itself and, consequently, in element cycling (Ratón et al.2012). In addition to potential for pathogen inhibition, cellulase production in rhizobacteria plays an important role in the penetration of these organisms into the host plant during colonization (ParionaLlanos et al. 2010). 
The BU96 isolate from the Dyella genus isolated herein was the only isolate able to degrade chitin. Microorganisms belonging to this genus have been isolated from soil and described as chitindegrading agents (Lee and Lee 2009). Although the presence of chitinolytic bacteria is ubiquitous, it is estimated that only $1 \%$ of rhizobacteria isolated from wheat, rice and maize present chitinolytic potential (Someya et al. 2011), which reinforces the low number of chitinolytics found in this study. The lytic enzymes cellulases and chitinases were selected for this screening since they are considered limiting factors for the growth of pathogenic fungi, as their lytic action is capable of causing degradation of the structural matrix of the fungal cell wall (El-Sayed et al. 2014).

Sugarcane is attacked by several pathogens such as viruses, bacteria, nematodes, insects and fungi. These organisms cause a number of productivity losses (Zhang et al. 2015). Among the main fungi species that attack sugarcane is $F$. moniliforme, which causes changes in leaf and stem morphology in non-pest-tolerant varieties (Lin et al. 2014, 2015). In this sense, rhizobacteria have been reported as biocontrol agents against pathogenic F. moniliforme strains (Hebbar et al. 1992, Figueroa-López et al. 2016).

Bacteria belonging to the Burkholderia genus are noteworthy with regard to the inhibition of the F. moniliforme pathogen. Several bacteria belonging to this genus isolated from different environments, such as tomato (Omar et al. 2006), barley (Simonetti et al. 2018) and soil in the Amazon region (Silva et al. 2012), are also capable of inhibiting the growth of phytopathogenic Fusarium strains. Some microorganisms belonging to this genus are believed to produce the antibiotic pyrrolnitrine, which is a fungus respiratory chain inhibitor (Parke and Gurian-Sherman 2001).

In vitro antagonistic test is important for the detection of potential biocontrol agents, especially in the presence of numerous isolates. However, theres is no guarantees that microorganisms producing antifungal substances in vitro will produce the same effects when inoculated in plants (Knudsen et al. 1997). In this sense, Shehata et al. (2016), simultaneously evaluated, in vitro and in vivo, the antifungal activity of 190 endophytic bacteria against the pathogen Sclerotinia homoeocarpa. These authors observed that out of 5 positive microorganisms in the in vitro tests, only 3 had in vivo activity. To produce antagonistic effects in vivo, microorganisms must be able to properly colonize the plant, settle in the plant tissue affected by the pathogen and survive the competition with the host's natural microbiota (Pliego et al. 2011, Deketelaere et al. 2017).

It is recommended that the inoculant candidate presents the highest number of in vitro plant growth promoting traits, since this would lead to a higher probability of survival in the field, due to their ability to use several substrates (Rana et al. 2011). In this sense, the isolates: Sphingobium yanoikuyae (BU32), Rhizobium sp. (NC24), Enterobacter sp. (NC25) and Enterobacter sp. (NU33) are noteworthy in this study due to their ability to produce IAA, as well as the ability to solubilize phosphate, and microorganisms belonging to the Burkholderia genus, namely NC97, BU95, NU31, NU21 and NU92, due to their simultaneous ability to solubilize phosphate and promote biocontrol. In addition, it is suggested that these bacteria can be applied in mixed form in greenhouse and field evaluations in subsequent studies.

\section{ACKNOWLEDGMENTS}

The authors would like to thank Jalles Machado and Goiasa-Goiatuba Álcool Ltda for allowing and assisting in the collection of rhizospheric soil, to the Centro de Tecnologia Canavieira (CTC) for granting the Fusarium moniliforme strain used in the study and to Professor Maria Carolina Quecine Verdi (Esalq-USP) for kindly granting the 
Azospirillum brasilense strain used as a positive control. The authors would also like to thank the Coordenação de Aperfeiçoamento de Pessoal de Nível Superior (CAPES) for the first author's scholarship and to the Programa de Pós-Graduação em Ciências Ambientais (CIAMB) for financial assistance.

\section{REFERENCES}

AHEMAD M AND KIBRET M. 2014. Mechanisms and applications of plant growth promoting rhizobacteria: Current perspective. J King Saud Univ Sci 26: 1-20.

ALTSCHUL SF, GISH W, MILLER W, MYERS EW AND LIPMAN DJ. 1990. Basic local alignment search tool. J Mol Bio 215: 403-410.

AMBROSINI A, BENEDUZI A, STEFANSKI T, PINHEIRO FG, VARGAS LK AND PASSAGLIA LMP. 2012. Screening of plant growth promoting Rhizobacteria isolated from sunflower (Helianthus annuus L.). Plant Soil 356: 245-264.

ANAND S, SANGWAN N, LATA P, KAUR J, DUA A, SINGH AK AND LAL R. 2012. Genome sequence of Sphingobium indicum B90A, a hexachlorocyclohexanedegrading bacterium. J Bacteriol 194: 4471-4472.

BALDANI JI, REIS VM, VIDEIRA SS, BODDEY LH AND BALDANI VLD. 2014. The art of isolating nitrogenfixing bacteria from non-leguminous plants using $\mathrm{N}$-free semi-solid media: a practical guide for microbiologists. Plant Soil 384: 413-431.

BENEDUZI A, MOREIRA F, COSTA PB, VARGAS LK, LISBOA BB, FAVRETO R AND PASSAGLIA LMP. 2013. Diversity and plant growth promoting evaluation abilities of bacteria isolated from sugarcane cultivated in the South of Brazil. Appl Soil Ecol 63: 94-104.

BENEDUZI A, PERES D, DA COSTA PB, BODANESE ZANETTINI MH AND PASSAGLIA LMP. 2008. Genetic and phenotypic diversity of plant-growth-promoting bacilli isolated from wheat fields in southern Brazil. Res Microbiol 159: 244-250.

BERS K, SNIEGOWSKI K, DE MOT R AND SPRINGAEL D. 2012. Dynamics of the linuron hydrolase libA gene pool size in response to linuron application and environmental perturbations in agricultural soil and onfarm biopurification systems. Appl Environ Microbiol 78: 2783-2789.

BHARDWAJ D, ANSARI MW, SAHOO RK AND TUTEJA N. 2014. Biofertilizers function as key player in sustainable agriculture by improving soil fertility, plant tolerance and crop productivity. Microb Cell Fact 13: 1-10.
BRANDL MT AND LINDOW SE. 1998. Contribution of indole-3-acetic acid production to the epiphytic fitness of Erwinia herbicola. Appl Environ Microbiol 64: 32563263.

BURBANO CS, LIU Y, RÖSNER KL, REIS VM, CABALLERO-MELLADO J, REINHOLD-HUREK B AND HUREK T. 2011. Predominant nifH transcript phylotypes related to Rhizobium rosettiformans in fieldgrown sugarcane plants and in Norway spruce. Environ Microbiol Rep 3: 383-389.

CAPPUCCINO JG AND SHERMAN N. 1996. Microbiology: A Laboratory Manual. 6. ed., New York: The Benjamin/ Cummings Publishing Company, 208 p.

CASTRO-GONZALEZ R, MARTINEZ-AGUILAR L, RAMIREZ-TRUJILLO A, ESTRADA-DE LOS SANTOS $P$ AND CABALLERO-MELLADO J. 2011. High diversity of culturable Burkholderia species associated with sugarcane. Plant Soil 345: 155-169.

CATTELAN AJ. 1999. Métodos quantitativos para determinação de características bioquímicas e fisiológicas associadas com bactérias promotoras de crescimento vegetal. Londrina: Embrapa Soja, 36 p.

CROWDER DW AND REGANOLD JP. 2015. Financial competitiveness of organic agriculture on a global scale. Proc Natl Acad Sci USA 112: 7611-7616.

DAHAL B, NANDAKAFLE G, PERKINS L AND BRÖZEL VS. 2017. Diversity of free-Living nitrogen fixing Streptomyces in soils of the badlands of South Dakota. Microbiol Res 195: 31-39.

DAI Z, GUO X, YIN H, LIANG Y, CONG J AND LIU X. 2014. Identification of nitrogen-fixing genes and gene clusters from metagenomic library of acid mine drainage. PLOS ONE 9: 1-9.

DEKETELAERE S, TYVAERT L, FRANÇA SC AND HÖFTE M. 2017. Desirable traits of a good biocontrol agent against Verticillium wilt. Front Microbiol 8: 1-23.

DEY R, PAL KK, BHATT DM AND CHAUHAN SM. 2004. Growth promotion and yield enhancement of peanut (Arachis hypogaea L.) by application of plant growthpromoting rhizobacteria. Microbiol Res 159: 371-394.

DI FRANCO C, BECCARI E, SANTINI T, PISANESCHI G AND TECCE G. 2002. Colony shape as a genetic trait in the pattern-forming Bacillus mycoides. BMC Microbiol 2: $1-15$.

DOBEREINER J, MARRIEL IE AND NERY M. 1976. Ecological distribution of Spirillum lipoferum Beijerinck. Can J Microbiol 22: 1464-1473.

DUANGPAENG A, PHETCHARAT P, CHANTHAPHO S, BOONKANTONG N AND OKUDA N. 2012. The study and development of endophytic bacteria for enhancing organic rice growth. Procedia Eng 32: 172-176.

EL-SAYED WS, AKHKHA A, EL-NAGGAR MY AND ELBADRY M. 2014. In vitro antagonistic activity, plant 
growth promoting traits and phylogenetic affiliation of rhizobacteria associated with wild plants grown in arid soil. Front Microbiol 5: 1-11.

FERREIRA DF. 2011. Sisvar: a computer statistical analysis system. Cienc Agrotecnol 35: 1039-1042.

FIGUEROA-LÓPEZ AM, CORDERO-RAMÍREZ JD, MARTÍNEZ-ÁLVAREZ JC, LÓPEZ-MEYER M, LIZÁRRAGA-SÁNCHEZ GJ, FÉLIX-GASTÉLUM R AND MALDONADO-MENDOZAIE. 2016. Rhizospheric bacteria of maize with potential for biocontrol of Fusarium verticillioides. SpringerPlus 5: 330.

FISCHER D, PFITZNER B, SCHMID M, SIMÕES-ARAÚJO JL, REIS VM, PEREIRA W AND HARTMANN A. 2012. Molecular characterisation of the diazotrophic bacterial community in uninoculated and inoculated field-grown sugarcane (Saccharum sp.). Plant Soil 356: 83-99.

GABY JC AND BUCKLEY DH. 2012. A comprehensive evaluation of PCR primers to amplify the nifH gene of nitrogenase. PLoS ONE 7: 1-12.

GAYATHRI S, SARAVANAN D, RADHAKRISHNAN M, BALAGURUNATHAN R AND KATHIRESAN K. 2010. Bioprospecting potential of fast growing endophytic bacteria from leaves of mangrove and salt-marsh plant species. Ind J Biotechnol 9: 397-402.

GOLDEMBERG J, COELHO ST AND GUARDABASSI P. 2008. The sustainability of ethanol production from sugarcane. Energy Policy 36: 2086-2097.

GOPALAKRISHNAN S, SRINIVAS V, ALEKHYA G AND PRAKASH B. 2015. Effect of plant growth-promoting Streptomyces sp. on growth promotion and grain yield in chickpea (Cicer arietinum L.). 3 Biotech 5: 1-8.

GORDON SA AND WEBER RP. 1951. Colorimetric estimation of indoleacetic acid. Plant Physiol 26: 192-195.

GTARI M, GHODHBANE-GTARI F, NOUIOUI I, BEAUCHEMIN N AND TISA LS. 2012. Phylogenetic perspectives of nitrogen-fixing actinobacteria. Arch Microbiol 194: 3-11.

HAMDALI H, HAFIDI M, VIROLLE MJ AND OUHDOUCH Y. 2008. Rock phosphate-solubilizing Actinomycetes: Screening for plant growth-promoting activities. World J Microbiol Biotechnol 24: 2565-2575.

HAYAT R, ALI S, AMARA U, KHALID R AND AHMED I. 2010. Soil beneficial bacteria and their role in plant growth promotion: A review. Ann Microbiol 60: 579-598.

HEBBAR KP, DAVEYAGANDDART PJ. 1992. Rhizobacteria of maize antagonistic to Fusarium moniliforme, a soilborne fungal pathogen: isolation and identification. Soil Biol Biochem 24: 979-987.

HIREL B, TÉTU T, LEA PJ AND DUBOIS F. 2011. Improving nitrogen use efficiency in crops for sustainable agriculture. Sustainability 3: 1452-1485.

HOANG VA, KIM YJ, NGUYEN NL, KANG CH, KANG JP, SINGH P AND YANG DC. 2015. Microbacterium rhizomatis sp. nov., a $\beta$-glucosidase-producing bacterium isolated from rhizome of Korean mountain ginseng. Int $\mathrm{J}$ Syst Evol Microbiol 65: 3196-3202.

INUI-KISHI RN, KISHI LT, PICCHI SC, BARBOSA JC, LEMOS MTO, MARCONDES J AND LEMOS EGM. 2012. Phosphorus solubilizing and IAA production activities in plant growth promoting rhizobacteria from brazilian soils under sugarcane cultivation. ARPN J Eng Appl Sci 7: 1446-1454.

JÄRVAN M AND EDESI L. 2015. Nitrogen cycle bacteria in soils of organically and conventionally managed crop rotations. Zemdirbyste-Agriculture 102: 15-22.

JI SH, GURURANI MA AND CHUN SC. 2014. Isolation and characterization of plant growth promoting endophytic diazotrophic bacteria from Korean rice cultivars. Microbiol Res 169: 83-98.

JOSEPH B, PATRA RR AND LAWRENCE R. 2007. Characterization of plant growth promoting rhizobacteria associated with chickpea (Cicer arietinum L.). Int J Plant Prod 1: 141-151.

KANCHISWAMY CN, MALNOY M AND MAFFEI ME. 2015. Bioprospecting bacterial and fungal volatiles for sustainable agriculture. Trends Plant Sci 20: 206-211.

KARAGÖZ K, ATEŞ F, KARAGÖZ H, KOTAN R AND ÇAKMAKÇI R. 2012. Characterization of plant growthpromoting traits of bacteria isolated from the rhizosphere of grapevine grown in alkaline and acidic soils. Eur J Soil Biol 50: 144-150.

KASANA RC, SALWAN R, DHAR H, DUTT S AND GULATI A. 2008. A rapid and easy method for the detection of microbial cellulases on agar plates using Gram's iodine. Curr Microbiol 57: 503-507.

KAVAMURA VN, SANTOS SN, SILVA JL, PARMA MM, ÁVILA LA, VISCONTI A AND MELO IS. 2013. Screening of Brazilian cacti rhizobacteria for plant growth promotion under drought. Microbiol Res 168: 183-191.

KNUDSEN IMB, HOCKENHULL J, JENSEN DF, GERHARDSON B, HÖKEBERG M, TAHVONEN R, TEPERI E, SUNDHEIM L AND HENRIKSEN B. 1997. Selection of biological control agents for controlling soil and seed-borne diseases in the field. Eur J Plant Pathol 103: 775-784.

KRUASUWAN W AND THAMCHAIPENET A. 2016. Diversity of Culturable Plant Growth-Promoting Bacterial Endophytes Associated with Sugarcane Roots and Their Effect of Growth by Co-Inoculation of Diazotrophs and Actinomycetes. J Plant Growth Regul 4: 1074-1087.

KUKLA M, POCINICZAK T AND PIOTROWSKA-SEGET Z. 2014. Diversity of endophytic bacteria in Lolium perenne and their potential to degrade petroleum hydrocarbons and promote plant growth. Chemosphere 117: 40-46. 
KUMAR M. 2014. Bacteria involving in nitrogen fixation and their evolutionary correlation. Int J Curr Microbiol App Sci 3: 824-830.

KUSS AV, KUSS VV, LOVATO T AND FLÔRES ML. 2007. Fixação de nitrogênio e produção de ácido indolacético in vitro por bactérias diazotróficas endofíticas. Pesqui Agropecu Bras 42: 1459-1465.

LANE D. 1991. 16S/23S rRNA sequencing. In: Stackebrandt $\mathrm{E}$ and Goodfellow M (Eds), Nucleic Acid Techniques in Bacterial Systematics. Chichester: J Wiley \& Sons, p. 115147.

LEBARON P, GHIGLIONE JF, FAJON C, BATAILLER N AND NORMAND P. 1998. Phenotypic and genetic diversity within a colony morphotype. FEMS Microbiol Lett 160: 137-143.

LEE DW AND LEE SD. 2009. Dyella marensis sp. nov., isolated from cliff soil. Int J Syst Evol Microbiol 59: 13971400.

LIMA RC, KOZUSNY-ANDREANI DI, ANDREANI JUNIOR R AND FONSECA L. 2011. Caracterização Fenotípica de Bactérias Diazotróficas Endofíticas Isoladas de Cana de Açúcar. Revista Facultad Nacional de Agronomía - Mendellín 64: 5803-5813.

LIN L, LI Z, HU C, ZHANG X, CHANG S, YANG L AND $A N$ Q. 2012. Plant growth-promoting nitrogen-fixing Enterobacteria are in association with sugarcane plants growing in Guangxi, China. Microbes Environ 27: 391398.

LIN Z, XU S, QUE Y, WANG J, COMSTOCK JC, WEI J AND ZHANG M. 2014. Species-specific detection and identification of Fusarium species complex, the causal agent of sugarcane pokkah boeng in China. PLoS ONE 9: 1-13.

LIN Z, YUJUAN Z, YOUXIONG Q AND RUKAI C. 2015. Characterization of Fusarium verticillioide Isolates from Pokkah Boeng on Sugarcane and The Disease Incidence In Field. J Microbiol Exp 5: 61-68.

LUVIZOTTO DM, MARCON J, ANDREOTE FD, DINIANDREOTE F, NEVES AAC, ARAÚJO WL AND PIZZIRANI-KLEINER AA. 2010. Genetic diversity and plant-growth related features of Burkholderia spp. from sugarcane roots. World J Microbiol Biotechnol 26: 18291836.

MACKELLAR D, LIEBER L, NORMAN JS, BOLGER A, TOBIN C, MURRAY JW AND PRELL J. 2016. Streptomyces thermoautotrophicus does not fix nitrogen. Sci Rep 6: 1-12.

MADHAIYAN M, POONGUZHALI S, LEE JS, LEE KC AND HARI K. 2011. Bacillus rhizosphaerae sp. nov., an novel diazotrophic bacterium isolated from sugarcane rhizosphere soil. Antonie van Leeuwenhoek 100: 437-444.

MARQUES APGC, PIRES C, MOREIRA H, RANGEL AOSS AND CASTRO PML. 2010. Assessment of the plant growth promotion abilities of six bacterial isolates using Zea mays as indicator plant. Soil Biol Biochem 42: 12291235.

NAUTIYAL CS. 1999. An efficient microbiological growth medium for screening phosphate solubilizing microorganisms. FEMS Microbiol Lett 170: 265-270.

NICOLAISEN MH, BÆLUM J, JACOBSEN CS AND SØRENSEN J. 2008. Transcription dynamics of the functional $t f d$ A gene during MCPA herbicide degradation by Cupriavidus necator AEO106 (pRO101) in agricultural soil. Env Microbiol 10: 571-579.

NOUMAVO PA, AGBODJATO NA, BABA-MOUSSA F, ADJANOHOUN AAND BABA-MOUSSA L. 2016. Plant growth promoting rhizobacteria: Beneficial effects for healthy and sustainable agriculture. Afr J Biotechnol 15: 1452-1463.

OLIVEIRA ZMD. 2009. Rizobactérias promotoras de crescimento vegetal isoladas de cana-de-açúcar sob fertilização orgânica e/ou convencional (Doctoral thesis, Universidade de São Paulo), 165 p.

OMAR I, O’NEILL TM AND ROSSALL S. 2006. Biological control of Fusarium crown and root rot of tomato with antagonistic bacteria and integrated control when combined with the fungicide carbendazim. Plant Pathol 55: 92-99.

PARIONA-LLANOS R, IBANEZ SFF, SOTO GHH AND BARBOSA HR. 2010. Influence of organic fertilization on the number of culturable diazotrophic endophytic bacteria isolated from sugarcane. Eur J Soil Biol 46: 387-393.

PARK M, KIM C, YANG J, LEE H, SHIN W, KIM S AND SA T. 2005. Isolation and characterization of diazotrophic growth promoting bacteria from rhizosphere of agricultural crops of Korea. Microbiol Res 160: 127-133.

PARKE JL AND GURIAN-SHERMAN D. 2001. Diversity of the Burkholderia cepacia complex and Implications for Risk Assessment of Biological Control Strains. Annual Rev Phytopathol 39: 225-258.

PASSARI AK, MISHRA VK, GUPTA VK, YADAV MK, SAIKIA R AND SINGH BP. 2015. In vitro and in vivo plant growth promoting activities and DNA fingerprinting of antagonistic endophytic actinomycetes associates with medicinal plants. PLoS ONE 10: 1-19.

PAUNGFOO-LONHIENNE C, LONHIENNE TGA, YEOH YK, WEBB RI, LAKSHMANAN P, CHAN CX AND HUGENHOLTZ P. 2014. A new species of Burkholderia isolated from sugarcane roots promotes plant growth. Microb Biotechnol 7: 142-154.

PISA G, MAGNANI GS, WEBER H, SOUZA EM, FAORO H, MONTEIRO RA AND CRUZ LM. 2011. Diversity of 16S rRNA genes from bacteria of sugarcane rhizosphere soil. Braz J Med Biol Res 44: 1215-1221.

PLIEGO C, RAMOS C, DE VICENTE A AND CAZORLA FM. 2011. Screening for candidate bacterial biocontrol 
agents against soilborne fungal plant pathogens. Plant soil 340: 505-520.

POLY F, MONROZIER LJ AND BALLY R. 2001. Improvement in the RFLP procedure for studying the diversity of nif $\mathrm{H}$ genes in communities of nitrogen fixers in soil. Res Microbiol 152: 95-103.

RANAA, SAHARAN B, JOSHI M, PRASANNA R, KUMAR K AND NAIN L. 2011. Identification of multi-trait PGPR isolates and evaluating their potential as inoculants for wheat. Ann Microbiol 61: 893-900.

RATÓN TMO, YANO R, IOCHEVET E, FLOH S AND JESU M. 2012. Isolation and characterisation of aerobic endospore forming Bacilli from sugarcane rhizosphere for the selection of strains with agriculture potentialities. World J Microbiol Biotechnol 28: 1593-1603.

RAYMOND J, SIEFERT JL, STAPLES CR AND BLANKENSHIP RE. 2004. The natural history of nitrogen fixation. Mol Biol Evol 21: 541-554.

RODRIGUES AA, FORZANI MV, SOARES RDS, SIBOV ST AND VIERA JDG. 2016. Isolation and selection of plant growth-promoting bacteria associated with sugarcane. Pesq Agropec Trop 46: 149-158.

SADEGHI A, KARIMI E, DAHAJI PA, JAVID MG, DALVAND Y AND ASKARI H. 2012. Plant growth promoting activity of an auxin and siderophore producing isolate of Streptomyces under saline soil conditions. World J Microbiol Biotechnol 28: 1503-1509.

SAGAR A, DEBBARMA V, ABRAHAM T, SHUKLA PK AND RAMTEKE PW. 2017. Functional Diversity of Soil Bacteria from Organic Agro Ecosystem. Int J Curr Microbiol App Sci 6: 3500-3518.

SAMBROOK JR AND RUSSELL D. 2001. Molecular cloning: a laboratory manual. Q Rev Biol 76: 348-349.

SANTI FERRARA FI, OLIVEIRA ZM, GONZALES HHS, FLOH EIS AND BARBOSA HR. 2012. Endophytic and rhizospheric enterobacteria isolated from sugarcane have different potentials for producing plant growth-promoting substances. Plant Soil 353: 409-417.

SANTOS IB, LIMA DRM, BARBOSA JG, OLIVEIRA JTC, FREIRE FJ AND KUKLINSKY-SOBRAL J. 2012. Diazotrophic Bacteria Associated to Roots of Sugarcane: Inorganic Phosphate Solubilization and the Salinity Tolerance. Biosc J 28: 142-149.

SCHULTZ N, SILVA JA, SOUSA JS, MONTEIRO RC, OLIVEIRA RP, CHAVES VA AND URQUIAGA S. 2014. Inoculation of sugarcane with diazotrophic bacteria. Rev Bras Cienc Solo 38: 407-414.

SEVERIANO EC, DE OLIVEIRA GC, CURI N AND DIAS JÚNIOR MS. 2009. Potencial de uso e qualidade estrutural de dois solos cultivados com cana-de-açúcar em Goianésia (GO). Rev Bras Cienc Solo 33: 159-168.

SGROY V, CASSN F, MASCIARELLI O, DEL PAPA MF, LAGARES A AND LUNA V. 2009. Isolation and characterization of endophytic plant growth-promoting (PGPB) or stress homeostasis-regulating (PSHB) bacteria associated to the halophyte Prosopis strombulifera. Appl Microbiol Biotechnol 85: 371-381.

SHEHATA HR, LYONS EM, JORDAN KS AND RAIZADA MN. 2016. Relevance of in vitro agar based screens to characterize the anti-fungal activities of bacterial endophyte communities. BMC Microbiol 16: 1-7.

SILVA K, CASSETARI AS, SILVA LA, DE BRANDT E, PINNOCK E, VANDAMME P AND SOUZA MFM.

2012. Diazotrophic Burkholderia species isolated from the Amazon region exhibit phenotypical, functional and genetic diversity. Syst Appl Microbiol 35: 253-262.

SIMONETTI E, ROBERTS IN, MONTECCHIA MS, GUTIERREZ-BOEM FH, GOMEZ FM AND RUIZ JA. 2018. A novel Burkholderia ambifaria strain able to degrade the mycotoxin fusaric acid and to inhibit Fusarium spp. growth. Microbiol Res 206: 50-59.

SOLANKI MK, WANG Z, WANG FY, LI CN, LAN TJ, SINGH RK AND LI YR. 2017. Intercropping in Sugarcane Cultivation Influenced the Soil Properties and Enhanced the Diversity of Vital Diazotrophic Bacteria. Sugar Tech 19: 136-147.

SOMEYA N, IKEDA S, MOROHOSHI T, TSUJIMOTO MN, YOSHIDA T, SAWADA H AND TSUCHIYA K. 2011. Diversity of Culturable Chitinolytic Bacteria from Rhizospheres of Agronomic Plants in Japan. Microbes Environ 26: 7-14.

STAMFORD TL, ARAÚJO JM AND STAMFORD NP. 1998. Atividade enzimática de micro-organismos isolados de jacatupé (Pachyrhizus erosos L. Urban). Ciênc Tecnol Aliment 18: 382-385.

SURAPAT W, PUKAHUTA C, RATTANACHAIKUNSOPON P, AIMI T AND BOONLUE S. 2013. Characteristics of phosphate solubilization by phosphate-solubilizing bacteria isolated from agricultural chili soil and their efficiency on the growth of chili (Capsicum frutescens L. cv. Hua Rua). Chiang Mai J Sci 40: 11-25.

SZILAGYI-ZECCHIN VJ, IKEDA AC, HUNGRIA M, ADAMOSKI D, KAVA-CORDEIRO V, GLIENKE C AND GALLI-TERASAWA LV. 2014. Identification and characterization of endophytic bacteria from corn (Zea mays L.) roots with biotechnological potential in agriculture. AMB Express 4: 1-10.

TAM HM AND DIEP CN. 2015. Isolation and Identification of Rhizospheric Bacteria in Sugarcane (Saccharum spp. L.) Cultivated on Acrisols and Ferrasols of Dong Nai Province, the Southeast of Vietnam. Am J Life Sci 3: 109118.

VEJAN P, ABDULLAH R, KHADIRAN T, ISMAIL S AND NASRULHAQ BA. 2016. Role of Plant Growth Promoting Rhizobacteria in Agricultural Sustainability-A Review. Mol 21: 573-583. 
VESSEY JK. 2003. Plant growth promoting rhizobacteria as biofertilizers. Plant Soil 255: 571-586.

WALPOLA BC AND YOON M. 2013. In vitro solubilization of inorganic phosphates by phosphate solubilizing microorganisms. Afr J Microbiol. Res 7: 3534-3541.

WONGPHATCHARACHAI M, STALEY C, WANG P, MONCADA KM, SHEAFFER CC AND SADOWSKY MJ. 2015. Predominant populations of indigenous soybean-nodulating Bradyrhizobium japonicum strains obtained from organic farming systems in Minnesota. J Appl Microbiol 118: 1152-1164.

XIA Y, DEBOLT S, DREYER J, SCOTT D AND WILLIAMS MA. 2015. Characterization of culturable bacterial endophytes and their capacity to promote plant growth from plants grown using organic or conventional practices. Front Plant Sci 6: 1-10.

XUN W, LI W, HUANG T, REN Y, XIONG W, MIAO Y, WEI R, LI D, SHEN Q AND ZHANG R. 2018. Long-term agronomic practices alter the composition of asymbiotic diazotrophic bacterial community and their nitrogen fixation genes in an acidic red soil. Biol Fertil Soils 2018: $1-11$.

YUAN CL, MOU CX, WU WL AND GUO YB. 2011. Effect of different fertilization treatments on indole-3-acetic acid producing bacteria in soil. J. Soils Sediments 11: 322-329.

ZEHR JP, JENKINS BD, SHORT SM AND STEWARD GF. 2003. Nitrogenase gene diversity and microbial community structure: a cross-system comparison. Environ Microbiol 5: 539-554.

ZHANG C, WANG J, TAO H, DANG X, WANG Y, CHEN M AND WANG Z. 2015. FvBck1, a component of cell wall integrity MAP kinase pathway, is required for virulence and oxidative stress response in sugarcane Pokkah Boeng pathogen. Front Microbiol 6: 1-12.

ZHAO L, XU Y, LAI X, SHAN C, DENG Z AND JI Y. 2015. Screening and characterization of endophytic Bacillus and Paenibacillus strains from medicinal plant Lonicera japonica for use as potential plant growth promoters. Braz J Microbiol 46: 977-989. 